\title{
SELECTION OF OPTIMAL CONDITIONS FOR CULTIVATION OF BACILLUS MEGATERIUM UCM B-5710 - PRODUCER OF KERATINASE
}

\author{
K.V. Avdiyuk, A.O. Roy \\ Zabolotny Institute of Microbiology and Virology, NAS of Ukraine, \\ 154 Acad. Zabolotny Str., Kyiv, 03143, Ukraine \\ e-mail:avdikat@i.ua
}

Every year the volume of production of poultry products all over the world is growing steadily. This contributes to a constant increase in the amount of by-products of poultry processing in the form of down and feather waste, which are dangerous for the environment due to the hard-to-degrade keratin protein and a large number of microbial pathogens. Therefore, the use of environmentally friendly methods for the destruction of keratin substrates due to keratinases of microorganisms is an urgent area of research. The aim of this work was to select the optimal cultivation conditions for the Bacillus megaterium strain UCM B-5710 to increase the activity of the keratinase synthesized by it. Methods. The culture was grown at $28{ }^{\circ} \mathrm{C}, 201 \mathrm{rpm}$ for 7 days on a basic nutrient medium containing defatted chicken feathers as the only source of carbon and nitrogen. The selection of optimal cultivation conditions was carried out according to the following parameters: temperature $\left(21^{\circ} \mathrm{C}, 28^{\circ} \mathrm{C}, 4{ }^{\circ} \mathrm{C}\right)$, stirring speed $(201 \mathrm{rpm}$, $212 \mathrm{rpm})$, amount of inoculum $(5 \%, 10 \%, 15 \%, 20 \%, 25 \%)$, the initial pH value of the nutrient medium (4.0-11.0), concentration of keratin-containing substrate $(0.1 \%, 0.2 \%, 0.5 \%, 1.0 \%, 1.5 \%$, $2.0 \%$ ), additional carbon source (glucose, galactose, lactose, maltose, sucrose, mannitol, potato and corn starch, soluble starch, soybean meal) and nitrogen $\left(\mathrm{NH}_{4} \mathrm{Cl}, \mathrm{NH}_{4} \mathrm{NO}_{3},\left(\mathrm{NH}_{4}\right)_{2} \mathrm{SO}_{4}, \mathrm{NaNO}_{3}\right.$, urea, peptone, tryptone, yeast extract and soybean meal) at a concentration of $1 \%$. Keratinase activity was assessed by the UV absorption at $280 \mathrm{~nm}$ of the hydrolysis products of keratin-containing raw materials. Protein was determined by the Lowry method. Results. The dynamics of the enzyme synthesis showed that the culture of B. megaterium UCM B-5710 exhibited the highest keratinase activity on the $3^{\text {rd }}$ day, and complete splitting of feathers was observed on the $4-5^{\text {th }}$ days. The selection of the concentration of the keratin-containing substrate showed that $0.5 \%$ is the optimal concentration. The study of the influence of the initial $\mathrm{pH}$ value of the nutrient medium indicates that the culture grew well at $p H$ 6.0-7.0 and $p H$ 9.0-11.0, but at $p H 8.0$ its growth was very weak. The culture exhibited the maximum keratinase activity at $p H$ 10.0. In addition, at this $p H$ value, complete splitting of feathers was visually observed. The influence of such a key factor as temperature on the growth and synthesis of the enzyme by B. megaterium UCM B-5710 culture demonstrated complete splitting of feathers already on the $2^{\text {nd }}$ day of cultivation at $42{ }^{\circ} \mathrm{C}$, at $21^{\circ} \mathrm{C}$ the culture split feathers very poorly. The introduction of the inoculum into the composition of the nutrient medium in an amount of $15 \%$ of the volume of the medium and the mixing intensity of $212 \mathrm{rpm}$ turned out to be optimal. Besides, it was shown that the introduction of an additional source of carbon or nitrogen had an ambiguous effect on the level of keratinase activity of B. megaterium UCM $B$-5710. Complete inhibition of enzyme synthesis was observed when ammonium sulfate was added to the nutrient medium, and partial inhibition was observed in the case of glucose, lactose, and maltose. Potato, corn, and soluble starch stimulated keratinase synthesis. The majority of inorganic nitrogen sources (ammonium chloride and nitrate) did not affect the synthesis of B. megaterium UCM B-5710 keratinase, while organic sources (urea, peptone, tryptone, yeast extract) increased the level of keratinase activity by 20-50\%. However, the most effective result was obtained using soybean meal, the addition of which to the nutrient medium increased the keratinase activity by 2.5 times. Conclusions. As a result of the studies, the optimal conditions for cultivation of the B. megaterium UCM B-5710 strain were selected: the optimum temperature for the growth and development of the culture is $42{ }^{\circ} \mathrm{C}$, the initial pH value is 10.0 , the stirring speed is $212 \mathrm{rpm}$ and the amount of inoculum introduced is $15 \%$, an additional source of carbon and nitrogen in the form of soybean meal at a concentration of $0.5 \%$. This made it possible to increase the activity of keratinase by 4 times.

Keywords: Bacillus megaterium UCM B-5710, keratinase, chicken feathers, additional source of carbon and nitrogen. 
The global waste of chicken feathers is 8.5 million tons annually and, unfortunately, this figure is increasing every year. At the same time, feather waste is a promising source of protein. As is known, keratin substrates contain up to 65 $80 \%$ of the potential protein (keratin), which can be converted into an accessible digestible form [1]. The main methods of disposal of these wastes are mechanical, hydrothermal and thermochemical treatment, which are expensive and energy intensive, and the resulting products have a low nutritional value and a deficiency of basic amino acids (methionine, lysine and tryptophan) [2]. The main component of keratin raw materials - keratin is a fibrillar protein with mechanical elasticity due to the presence of a large number of disulfide and hydrogen bonds, hydrophobic interactions, which cannot be cleaved by conventional proteases. It is found in feathers, hair, nails, hooves, horns, etc. [3]. In nature, keratin substrates do not accumulate, which indicates the existence of microorganisms that can destroy them. This is due to their synthesis of specific keratinase enzymes. Producers of these enzymes are found among bacteria (Nocardia, Bacillus, Pseudomonas), micromycetes (Keratinomyces, Microsporum, Trichophyton, Epidermophiton, Penicillium, Fusarium), actinomycetes (Streptomyces) and yeasts. Keratinase is an extracellular (mainly) proteolytic enzyme capable of breaking down insoluble keratin substrates. These properties of the enzyme are actively used in agriculture in the production of organic fertilizers and animal feed, in the leather, textile and food industries, in cosmetology and medicine, for the production of biofuels, biodegradable films, as well as in wastewater treatment $[1,3]$. Therefore, an important area of modern biotechnology is research aimed at expanding the possibilities of processing keratincontaining raw materials in order to ensure the safety and environmental friendliness of industries through the creation of waste-free and low-waste technologies with the maximum involvement of by-products of processing in the main production. In this regard, research aimed at finding effective producers of keratinolytic enzymes and the selection of optimal conditions and parameters for their cultivation, which would ensure an increase in the level of activity and yield of the enzyme, are relevant.

Materials and methods. We used bacterial strain of Bacillus megaterium, a keratinase producer, deposited under the number UCM B-5710 in the collection of microorganisms of the D.K. Zabolotny Institute of microbiology and virology, National Academy of Sciences of Ukraine.

To grow B. megaterium strain UCM B-5710, a basic nutrient medium of the following composition $(\mathrm{g} / \mathrm{L})$ was used: $\mathrm{K}_{2} \mathrm{HPO}_{4}-0.3 ; \mathrm{KH}_{2} \mathrm{PO}_{4}-0.4$; $\mathrm{MgSO}_{4} \times 7 \mathrm{H}_{2} \mathrm{O}-0.1 ; \mathrm{NaCl}-0.5$; fat-free chicken feathers - 5.0; $\mathrm{H}_{2} \mathrm{O}$ - up to $1.0 \mathrm{~L}$; $\mathrm{pH}$ 6.8-7.0. Chicken feathers were defatted with a mixture of chloroform and methanol in a 1:1 ratio.

As an inoculum, we used a daily culture of B. megaterium UCM B-5710 grown on a LuriaBertani medium of the following composition: peptone $-1 \%(\mathrm{w} / \mathrm{v})$, yeast extract $-0.3 \%(\mathrm{w} / \mathrm{v})$, $\mathrm{NaCl}-0.5 \%(\mathrm{w} / \mathrm{v}), \mathrm{pH} 7.2$ [4].

B. megaterium strain UCM B-5710 was grown by the submerged method in $0.75 \mathrm{~L}$ Erlenmeyer flasks with $100 \mathrm{~mL}$ of the above liquid nutrient medium at a temperature of $28{ }^{\circ} \mathrm{C}$, stirring speed $201 \mathrm{rpm}$ for 7 days. To obtain a supernatant (culture liquid supernatant, CLC), which was used for further studies, the culture liquid was centrifuged at $7000 \mathrm{~g}$ for $10 \mathrm{~min}$.

Keratinase activity (KerA) was determined by the UV absorption at $280 \mathrm{~nm}$ of the hydrolysis products of keratin-containing raw materials. The reaction mixture, consisting of $10 \mathrm{mg}$ of crushed defatted feathers, $2.5 \mathrm{~mL}$ of $0.05 \mathrm{M}$ boron-borate buffer ( $\mathrm{pH} 9.2$ ), and $1 \mathrm{~mL}$ of culture liquid, was kept in a thermostat at $37{ }^{\circ} \mathrm{C}$ for 3 hours, after which it was filtered. To determine KerA, two controls were used: (1) $10 \mathrm{mg}$ of crushed defatted feathers, $2.5 \mathrm{~mL}$ of $0.05 \mathrm{M}$ boron-borate buffer $(\mathrm{pH}$ 9.2), and $1 \mathrm{~mL}$ of distilled water; (2) $2.5 \mathrm{~mL}$ of $0.05 \mathrm{M}$ boron-borate buffer ( $\mathrm{pH} 9.2$ ) and $1 \mathrm{~mL}$ of culture liquid. The sum of the values of the two controls was subtracted from the values obtained by measuring the optical density of the filtrates at $\mathrm{A}_{280}$. The increase in absorption at $280 \mathrm{~nm}$ of the filtrate of the test sample relative to the controls was taken as the degree of protein release [5]. One unit of keratinase activity $(1 \mathrm{U} / \mathrm{mL}=0.01)$ was defined as the amount of enzyme that causes an increase in absorption by 0.01 for 3 hours of incubation.

Protein was determined by the Lowry method [6].

To determine the effect of substrate's concentration on keratinase production various substrate concentrations (\%) such as $0.1,0.2,0.5,1.0,1.5$, 2.0 were used as main nutrient sources separately for the production of keratinase. Fermentation was carried out with $5 \%$ inoculum at $28{ }^{\circ} \mathrm{C}$ for 7 days at $201 \mathrm{rpm}$. The $\mathrm{pH}$ and volume for the media were 7.0 and $100 \mathrm{~mL}$ respectively. 
To study the influence of carbon source, such as glucose, galactose, maltose, lactose, sucrose, mannitol, potato starch, corn starch, instant potato starch and soybean meal were supplemented at $1 \%(\mathrm{w} / \mathrm{w})$ level. To evaluate the effect of nitrogen source, $\mathrm{NH}_{4} \mathrm{Cl}, \mathrm{NH}_{4} \mathrm{NO}_{3},\left(\mathrm{NH}_{4}\right)_{2} \mathrm{SO}_{4}, \mathrm{NaNO}_{3}$, urea, peptone, tryptone, yeast extract and soybean meal were added in medium at $1 \%(\mathrm{w} / \mathrm{w})$ level.

To determine the suitable temperature for enzyme production, the culture media were incubated at 21,28 and $42{ }^{\circ} \mathrm{C}$ temperature (at $201 \mathrm{rpm}$ ) and for determination of optimum $\mathrm{pH}$ for keratinase production experiments were carried out from 4.0 to 11.0 separately. The $\mathrm{pH}$ was adjusted by using $0.1 \mathrm{~N} \mathrm{HCl}$ or $0.1 \mathrm{~N} \mathrm{NaOH}$.

The effect of different inoculum volumes $(5,10,15$ and $20 \%)$ in media were used to determine the appropriate inoculum volumes required for maximum production of enzyme.

The effect of agitation rate for keratinase production was studied at 201 and $212 \mathrm{rpm}\left(\right.$ at $28{ }^{\circ} \mathrm{C}$ temperature) independently.

All experiments were carried out in 3-5 replicates. The analysis of the obtained results was carried out by means of their statistical processing using the Student's t-test. The results, presented graphically, were drawn up using Microsoft Excel 2016.

Results. To obtain a highly active enzyme preparation, it is important not only to select a highly efficient producer, but also to select the optimal cultivation parameters.

The study of the dynamics of protein accumulation in a nutrient medium containing chicken feathers as the only source of carbon and nitrogen and the level of keratinase activity showed that the maximum protein content is observed on the $5-6^{\text {th }}$ day, and the keratinase activity on the $3^{\text {rd }}$ day (Fig. 1).

Keratin-containing substrates (feathers, hair, wool) act as an inducer of the synthesis of keratinolytic enzymes $[1,3]$. Therefore, it was important to determine the optimal concentration of feathers in the composition of the nutrient medium. As can be seen from Fig. 2, the culture of B. megaterium UCM B-5710 exhibited the highest keratinase activity at a feather concentration of $0.5 \%$, although good results were obtained at a substrate concentration of $1.5 \%(90 \%)$ and $2.0 \%$ (94\%).

An important factor influencing not only growth, but also the yield of the final product, is the selection of optimal parameters and cultivation conditions.

The optimal $\mathrm{pH}$ value of the nutrient medium for enzyme biosynthesis depends on the characteristics of the producer; however, bacteria generally develop best at a pH close to neutral (6.2-7.4) [7, 8]. To establish the optimum $\mathrm{pH}$ of the nutrient medium, B. megaterium UCM B-5710 strain was grown on a nutrient medium with $\mathrm{pH}$ values ranging from 4.0 to 11.0 (Fig. 3). The studied culture grew well at $\mathrm{pH} 6.0-7.0$ and $\mathrm{pH} 9.0-11.0$, but at $\mathrm{pH} 8.0$ its growth was very weak. The culture exhibited the maximum keratinase activity at $\mathrm{pH}$ 10.0. In addition, at this $\mathrm{pH}$ value, complete splitting of feathers was visually observed.

The amount of inoculum also significantly affects the growth of cells and the synthesis of the required product. The inoculum volume of $15 \%$ was optimal for the synthesis of B. megaterium UCM B-5710 keratinase (Fig. 4).

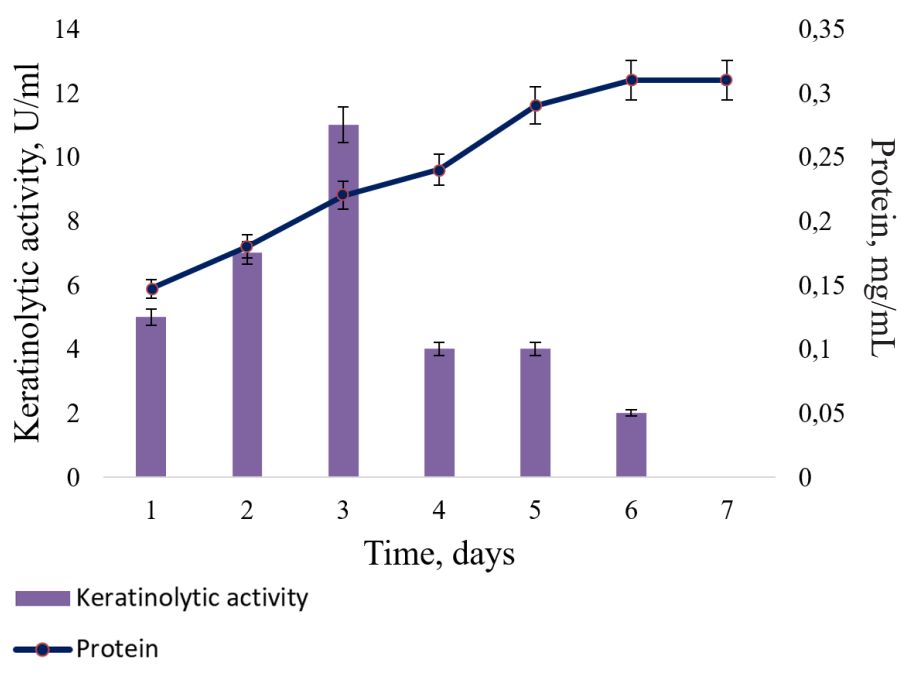

Fig. 1. Dynamics of protein accumulation in the nutrient medium and keratinase activity of B. megaterium UCM B-5710 


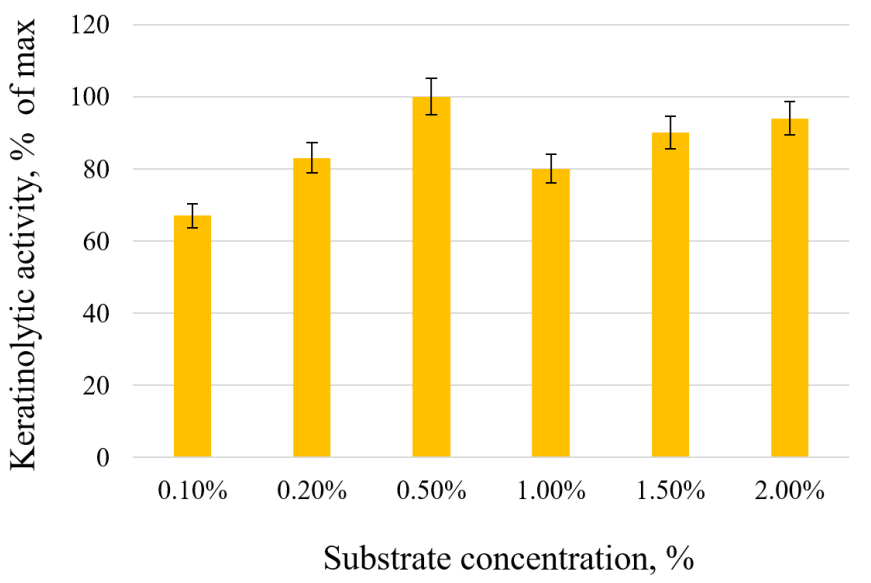

Fig. 2. Influence of substrate concentration on keratinase activity of B. megaterium UCM B-5710

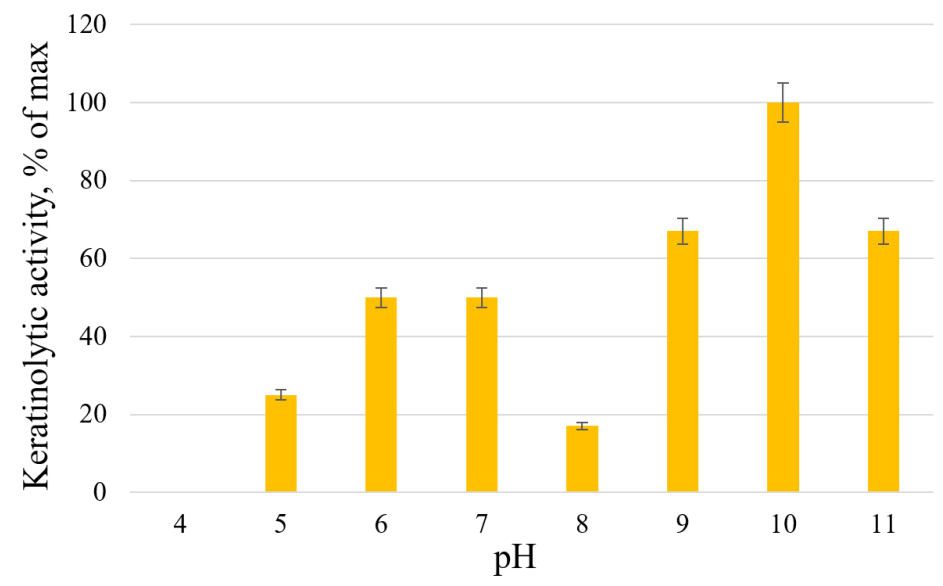

Fig. 3. Influence of the pH of nutrient medium on the synthesis of keratinase by the culture of B. megaterium UCM B-5710

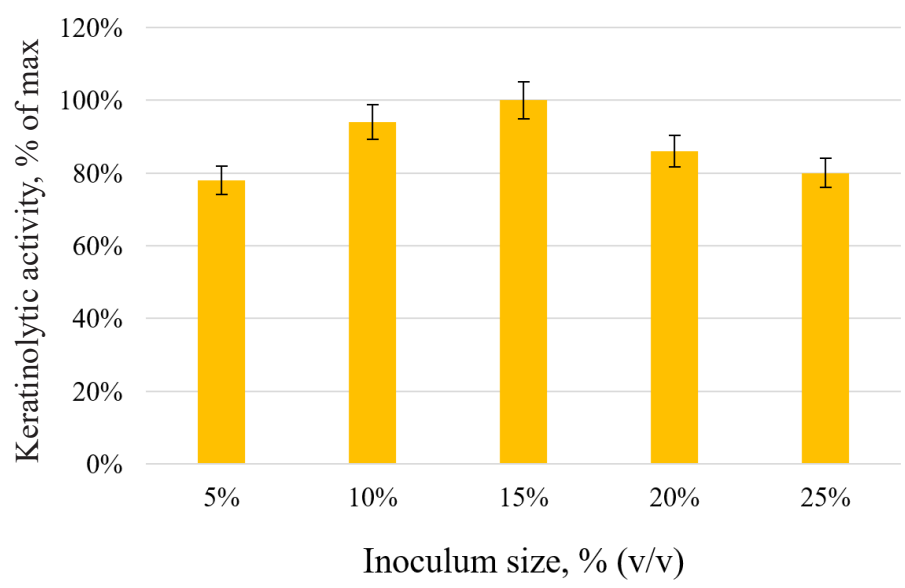

Fig. 4. Influence of the amount of inoculum on the keratinase activity of $B$. megaterium UCM B-5710

The temperature and intensity of stirring the culture medium are key factors affecting the synthesis of enzymes. The study of the effect of three temperatures $\left(21^{\circ} \mathrm{C}, 28{ }^{\circ} \mathrm{C}, 42{ }^{\circ} \mathrm{C}\right)$ and the rotation speed of the shackles $(201 \mathrm{rpm}$ and 212 $\mathrm{rpm}$ ) on the keratinase activity of $B$. megaterium UCM B-5710 showed that the temperature $42{ }^{\circ} \mathrm{C}$ and stirring speed $212 \mathrm{rpm}$ were optimal for the synthesis of the studied enzyme (Fig. 5). It is known from the literature that the synthesis of keratinases by bacteria of the genus Bacillus mainly occurs in the temperature range from 30 to $50{ }^{\circ} \mathrm{C}[7-11]$.

An important task of the study was the selection of optimal sources of carbon and nitrogen 
nutrition for B. megaterium UCM B-5710. These indicators are strictly individual and affect not only physiological indicators, but also the synthesis of enzymes. In this regard, a search was carried out for the optimal carbon and nitrogen components of the nutrient medium for the cultivation of B. megaterium strain UCM B-5710. Chicken feathers served as a source of carbon in the basic nutrient medium, to which various mono- (glucose, galactose), disaccharides (lactose, maltose, sucrose), sugar alcohol (mannitol), polysaccharides (potato and corn starch), as well as soybean meal were added. It was shown that the introduction of an additional carbon source had an effect on the level of keratinase activity of $B$. megaterium UCM B-5710 culture (Fig. 6). Partial inhibition of keratinase synthesis was observed when glucose, lactose and maltose were added to the nutrient medium. It is known from the literature that glucose inhibits the synthesis of many proteases, including keratinases [12]. According to the level of influence on the synthesis of B. megaterium UCM B-5710 keratinase, all carbon sources can be arranged in the following sequence: soybean meal $>$ corn starch $>$ potato starch $>$ galactose $>$ soluble starch $>$ control, sucrose, mannitol $>$ lactose, maltose $>$ glucose. As for nitrogen sources (Fig. 6), it was shown that the majority of inorganic nitrogen sources (ammonium chloride and nitrate) did not have an inducing effect on the synthesis of B. megaterium UCM B-5710 keratinase, only sodium nitrate caused a slight (by $10 \%$ ) increase in keratinase activity. On the

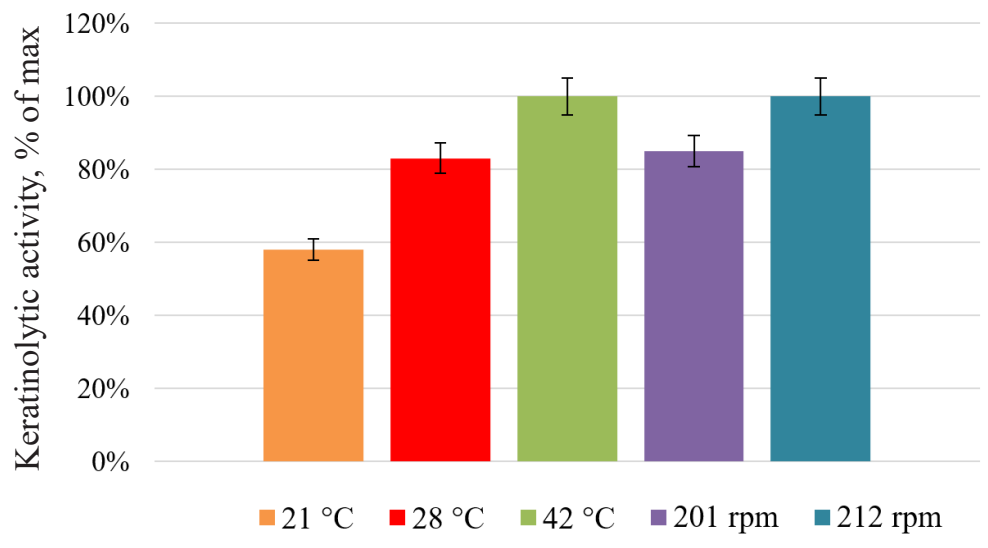

Temperature and agitation rate, ${ }^{\circ} \mathrm{C}$ and $\mathrm{rpm}$

Fig. 5. Influence of temperature and intensity of stirring on keratinase activity of B. megaterium UCM B-5710.

Note: The study of the effect of three temperatures $\left(21^{\circ} \mathrm{C}, 28^{\circ} \mathrm{C}, 42^{\circ} \mathrm{C}\right)$ and rotation speed of the shackles (201 rpm and $212 \mathrm{rpm})$ on the keratinase activity of $B$. megaterium UCM B-5710 was carried out at $201 \mathrm{rpm}$ and $28^{\circ} \mathrm{C}$, respectively.

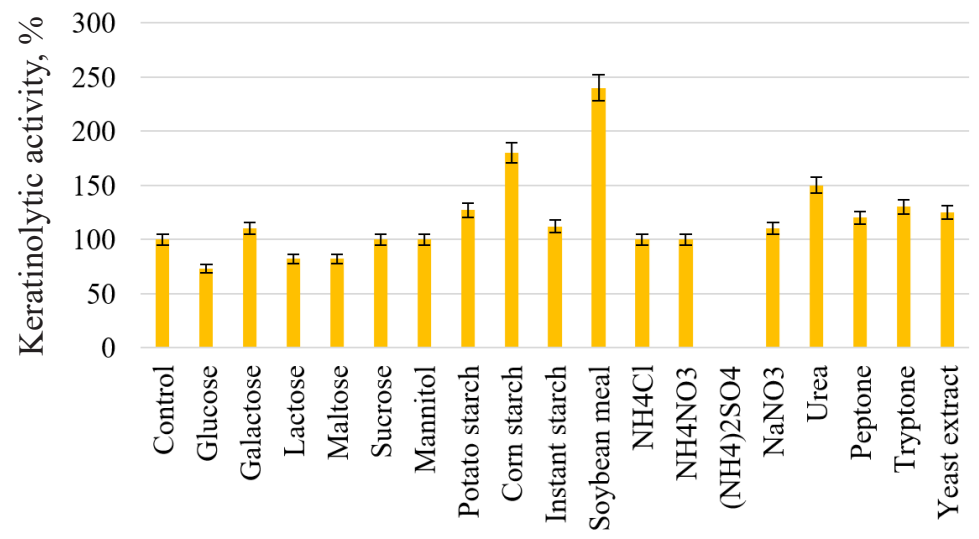

Carbon and nitrogen sources, $\%$

Fig. 6. Influence of carbon and nitrogen sources on keratinase activity of B. megaterium UCM B-5710.

Note: control - keratinase activity of $B$. megaterium UCM B-5710 when grown on a basic nutrient medium. The control value was taken as $100 \%$. 
contrary, with the addition of ammonium sulfate, complete inhibition of the enzyme synthesis was observed. A similar action is typical for B. cereus keratinase [13]. Organic sources of nitrogen (peptone, yeast extract, tryptone, urea) had a positive effect, increasing the level of keratinase activity by $20-50 \%$. The best result was obtained with the use of soybean meal, the addition of which to the nutrient medium increased the keratinase activity by 2.5 times. As is known, soybean meal is a source of both carbon and nitrogen, since it contains about 30-32 g of carbohydrates and up to $40 \mathrm{~g}$ of protein per $100 \mathrm{~g}$ of product.

The study of the optimal concentration of soybean meal $(0.2,0.5$ and $1.0 \%)$ as an additional source of carbon and nitrogen for the maximum production of keratinase showed that at a concentration of soybean meal of $0.5 \%$ the level of keratinase activity was the highest, while complete splitting of feathers was observed in the composition of the nutrient medium. The level of protein in the culture liquid when using $0.5 \%$ and $1 \%$ of soybean meal did not differ significantly ( 0.115 and $0.155 \mathrm{mg} / \mathrm{mL})$.

Thus, the introduction of an additional source of carbon and nitrogen into the composition of the basic nutrient medium, as well as the selection of optimal cultivation parameters, contributed to an increase in the keratinase activity of $B$. megaterium UCM B- 5710 by 4 times.

Discussion. To create a successful fermentation process using microorganisms and obtain an active product, it is necessary to select the optimal cultivation conditions. This is a key parameter for their practical application in the respective industries. Most microorganisms are demanding on the conditions of cultivation on artificial nutrient media, since their growth and development are influenced by both abiotic (temperature, acidity, aeration) and biotic (amount of biomass) environmental factors. These parameters directly affect not only the quality of the resulting product, but also the catalytic activity of the selected producer strain.

The composition of the medium and the cultivation conditions are two important factors that affect the yield of the enzyme during fermentation. It is known from the literature that most keratinases are inducible enzymes, the synthesis of which is stimulated by various keratin-containing substrates, such as feathers, wool, hair [1, 3, 14]. However, feathers are most often the inductors of keratinase synthesis $[9,15]$. In our studies, the feather concentration of $0.5 \%$ was optimal; similar data were obtained for the keratinase of Bacillus sp. UPM-AAG1 [14]. In the case of B. subtilis and Pseudomonas sp. LM19 feathers at a concentration of $10 \mathrm{~g} / \mathrm{L}[9,16,17]$ were the best substrate for the synthesis of keratinase, while for B. subtilis KD-N2 the best substrate for the synthesis of keratinase were hair at a concentration of $16 \mathrm{~g} / \mathrm{L}$ [4].

Basically, when growing keratinase-producing strains, the keratin-containing subtrate in the nutrient medium acts simultaneously as a source of both carbon and nitrogen. The introduction of additional sources of carbon and nitrogen can both stimulate and suppress the synthesis of enzymes by some microorganisms [18]. The maximum keratinase production of $B$. cereus was obtained in the wheat bran medium containing $1 \%$ of lactose [13]. The best sources of carbon and nitrogen (organic and inorganic) for the production of $B$. safensis LRF3X keratinase were feathers and galactose, as well as defatted nut and casein at a concentration of $1 \%$, respectively [17]. Our research has shown that the addition of soybean meal $(0.5 \%)$ has a positive effect on the synthesis of keratinase and the catalytic activity of B. megaterium UCM B-5710. Maximum keratinase production by Amycolatopsis sp. MBRL 40 was observed on a nutrient medium, one of the components of which was also soybean meal at a concentration of $0.5 \%(\mathrm{w} / \mathrm{v})$ [19]. It is known from the literature that glucose mainly acts as an inhibitor of microbial synthesis of many keratinases [12], which was partially observed in our case, although there are exceptions. Thus, the optimized nutrient medium for the maximum synthesis of B. licheniformis ZJUEL31410 keratinase contained glucose at a concentration of $20 \mathrm{~g} / \mathrm{L}$ [20].

Temperature is one of the key factors affecting the fermentation process. $42{ }^{\circ} \mathrm{C}$ is the optimal indicator for the synthesis of B. megaterium $\mathrm{UCM}$ B-5710 keratinase. Similar results are typical for the keratinase of Amycolatopsis sp. MBRL 40 [19], B. subtilis keratinase [21], and Streptomyces sp7 keratinase $\left(45^{\circ} \mathrm{C}\right)[22]$.

When studying the effect of the initial $\mathrm{pH}$ of the nutrient medium on the synthesis of $B$. megaterium UCM B-5710 keratinase, it was shown that the most optimal was $\mathrm{pH} 10.0$, as in the case of B. thuringiensis TS2 keratinase [11]. Similar results were obtained for the keratinase of Streptomyces sp7 [22] and the keratinase of B. subtilis [21], the maximum synthesis of which was observed at $\mathrm{pH}$ 11.0 . 
Stirring and aerating increases the solubility of oxygen in the environment for better microbial growth during aerobic fermentation and therefore affects enzyme production. The stirring intensity of $212 \mathrm{rpm}$ was found to be optimal for the synthesis of B. megaterium UCM B-5710 keratinase. For keratinase Streptomyces sp7, the optimal speed was $300 \mathrm{rpm}$ [22], for keratinase Bacillus aerius NSMk2 - $250 \mathrm{rpm}$ [23], and for keratinases Bacillus licheniformis-K51, Bacillus subtilis-K50, Bacillus sp.-K53 - 150 rpm, 200 rpm, 150 rpm, respectively [24].

The selection of the optimal cultivation parameters showed that in our studies a $15 \%$ inoculum was optimal for the synthesis of $B$. megaterium UCM B-5710 keratinase. For $B$. subtilis KD$\mathrm{N} 2$, the maximum synthesis of keratinase was observed when using a $10 \%$ inoculum [4], and for keratinase of Bacillus sp. UPM-AAG1 - $5 \%$ inoculum [14].

As a result of the studies, it was shown that the introduction of an additional source of carbon and nitrogen, the selection of optimal cultivation parameters induced the synthesis of $B$. megaterium UCM B-5710 keratinase and contributed to the complete splitting of feathers already on the $2^{\text {nd }}$ day.

Conclusions. Thus, as a result of the studies carried out, the optimal conditions for cultivation of B. megaterium UCM B-5710 strain were selected: the optimal temperature for the growth and development of the culture is $42{ }^{\circ} \mathrm{C}$ with the initial $\mathrm{pH}$ value of the nutrient medium 10.0, the stirring speed is $212 \mathrm{rpm}$, the amount of inoculum $-15 \%$, the amount of an additional source of carbon and nitrogen in the form of soybean meal $-0.5 \%$. All this contributed to a 4 -fold increase in the keratinase activity of $B$. megaterium UCM B-5710.

\section{ПІДБІР ОПТИМАЛЬНИХ УМОВ \\ КУЛЬТИВУВАННЯ В ACILLUS MEGATERIUM УКМ B-5710 - ПРОДУЦЕНТА КЕРАТИНАЗИ}

\author{
К.В. Авдіюк, А.О. Рой
}

\begin{abstract}
Інститут мікробіології і вірусологї ім. Д.К. Заболотного НАН Украӥни, вул. Академіка Заболотного, 154, Київ, 03143, Україна
\end{abstract}

\section{Резюме}

3 кожним роком об'єм виробництва продуктів птахівництва в усьому світі неухильно зростає. Це призводить до постійного зростання кількості побічних продуктів переробки птиці у вигляді пухо-пір'яних відходів, які становлять небезпеку для оточуючого середовища за рахунок білка кератину, що важко піддається деградації, і великої кількості мікробних патогенів. Тому використання екологічно чистих методів деструкції кератинових субстратів за рахунок кератиназ мікроорганізмів $\epsilon$ актуальною областю дослідження. Метою даної роботи був підбір оптимальних умов культивування штаму Bacillus megaterium УКМ В-5710 для підвищення активності синтезованої кератинази. Методи. Культуру B. megaterium УКМ В-5710 вирощували при $28{ }^{\circ} \mathrm{C}, 201$ об/хв протягом 7 діб на базовому живильному середовищі, що містить в якості єдиного джерела вуглецю і азоту знежирене куряче пір'я. Підбір оптимальних умов культивування проводили за такими параметрами: температура $\left(21^{\circ} \mathrm{C}, 28^{\circ} \mathrm{C}, 42{ }^{\circ} \mathrm{C}\right)$, швидкість перемішування (201 об/хв, 212 об/хв), кількість посівного матеріалу (5\%, $10 \%, 15 \%, 20 \%, 25 \%)$, початкове значення $\mathrm{pH}$ живильного середовища (4.0-11.0), концентрація кератинвмісного субстрату $(0,1 \%$, $0,2 \%, 0,5 \%, 1,0 \%, 1,5 \%, 2,0 \%$ ), додаткове джерело вуглецю (глюкоза, галактоза, лактоза, мальтоза, сахароза, маніт, картопляний і кукурудзяний крохмаль, розчинний крохмаль, соєве борошно) i азоту $\left(\mathrm{NH}_{4} \mathrm{Cl}, \mathrm{NH}_{4} \mathrm{NO}_{3},\left(\mathrm{NH}_{4}\right)_{2} \mathrm{SO}_{4}, \mathrm{NaNO}_{3}\right.$, сечовина, пептон, триптон, дріжджовий екстракт та соєве борошно) у концентрації $1 \%$. Кератиназну активність оцінювали за поглинанням в УФ при 280 нм продуктів гідролізу кератинвмісної сировини. Білок визначали методом Лоурі. Результати. Динаміка синтезу ферменту показала, що найвищу кератиназну активність культура $B$. megaterium УКМ B-5710 виявляла на 3 добу, а повне розщеплення пір'я спостерігалося на 4-5 добу. Підбір концен- 
трації кератинвмісного субстрату показав, що $0,5 \%$ є оптимальною концентрацією. Вивчення впливу вихідного значення $\mathrm{pH}$ живильного середовища свідчить про те, що культура добре росла при рН 6.0-7.0 і pH 9.0-11.0, однак при рН 8.0 iii ріст був дуже слабким. Максимальну кератиназну активність культура проявляла при рН 10.0. Крім того, при даному значенні рН візуально спостерігалося повне розщеплення пір'я. Вплив такого ключового фактору як температура на ріст і синтез ферменту культурою B. megaterium УКМ В-5710 продемонстрував повне розщеплення пір'я вже на 2 добу культивування при $42^{\circ} \mathrm{C}$. При $21^{\circ} \mathrm{C}$ культура дуже погано розщеплювала пір'я. Внесення інокулюму до складу живильного середовища в кількості 15 \% від об'єму середовища і інтенсивність перемішування 212 об/хв виявилися оптимальними параметрами. Крім того, було показано, що додавання додаткового джерела вуглецю або азоту неоднозначно впливало на рівень кератиназної активності культури $B$. megaterium УКМ В-5710. Повне інгібування синтезу ферменту спостерігалося при внесенні у живильне середовище сульфату амонію, а часткове - у випадку глюкози,

1. Li Q. Progress in Microbial Degradation of Feather Waste. Front Microbiol. 2019; 10:2717. doi: 10.3389/fmicb.2019.02717.

2. Sinkiewicz I, Śliwińska A, Staroszczyk H, Kołodziejska I. Alternative Methods of Preparation of Soluble Keratin from Chicken Feathers. Waste Biomass Valor. 2017; 8:1043-1048. doi: 10.1007/ s12649-016-9678-y.

3. Qingxin Li. Structure, Application and Biochemistry of Microbial Keratinases. Front Microbiol. 2021; 12:674345. doi:10.3389/fmicb. 2021.674345.

4. Cai C, Zheng X. Medium optimization for keratinase production in hair substrate by a new Bacillus subtilis KD-N2 using response surface methodology. Journal of Industrial Microbiology and Biotechnology. 2009; 36(7):875-883 doi:10.1007/s10295-009-0565-4.

5. Nickerson WJ, Noval JJ, Robison RS. Keratinase. I. Properties of the enzyme conjugate elaborated by Streptomyces fradiae. Biochim Biophys Acta. 1963; 77(1):73-86.

6. Varbanets LD, Matseliukh EV. Peptidases of microorganisms and methods of their investiga- лактози і мальтози. Картопляний, кукурудзяний i розчинний крохмаль стимулювали синтез кератинази. Більшість неорганічних джерел азоту (хлорид і нітрат амонію) не впливала на синтез кератинази B. megaterium УКМ В-5710, а органічні (сечовина, пептон, триптон, дріжджовий екстракт) підвищували рівень кератиназної активності на 20-50 \%. Однак найефективніший результат був отриманий при використанні соєвого борошна, додавання якого до складу живильного середовища сприяло підвищенню кератиназної активності у 2,5 рази. Висновки. У результаті проведених досліджень підібрано оптимальні умови культивування штаму B. megaterium УКМ В-5710: оптимальна температура для росту і розвитку культури $-42{ }^{\circ} \mathrm{C}$, початкове значення $\mathrm{pH}-10.0$, швидкість перемішування - 212 об/хв і кількість внесеного інокуляту - 15 \%, додаткове джерело вуглецю та азоту у вигляді соєвого борошна у концентрації 0,5 \%. Це дозволило в 4 рази підвищити активність кератинази.

Ключові слова: Bacillus megaterium УКМ В-5710, кератиназа, куряче пір'я, додаткове джерело вуглецю та азоту.

tions. Kyiv:Naukova Dumka; 2014.

7. Saigeetha S, Renitta E, Samrot A. Optimization of Keratinase Production and Utilization of Bacillus pumilus for Feather Degradation. J Pure Appl Microbiol. 2021; 14(4):2483-2489. doi:10.22207/JPAM.14.4.26.

8. Dhiva S, Ranjith KR, Prajisya P, Sona KP, Narendrakumar G, Prakash P, Emilin RR, Samrot AV. Optimization of Keratinase Production Using Pseudomonas aeruginosa SU-1 Having Feather as Substrate. 2020; 10(5):6540-6549. doi:10.33263/BRIAC105.65406549.

9. Cheng-gang Cai, Bing-gan Lou, Xiao-dong Zheng. Keratinase production and keratin degradation by a mutant strain of Bacillus subtilis. J Zhejiang Univ Sci B. 2008; 9(1):60-67. doi: 10.1631/jzus.B061620.

10. Barman NC, Zohora FT, Das KC, Mowla MG, Banu NA, Salimullah M, Hashem A. Production, partial optimization and characterization of keratinase enzyme by Arthrobacter sp. NFH5 isolated from soil samples. AMB Express. 2017; 7(1):181. doi: 10.1186/s13568-017-04626. 
11. Sivakumar T, Shankar T, Vijayabaskar P, Ramasubramanian V. Optimization for Keratinase Enzyme Production Using Bacillus thuringiensis TS2. Academic Journal of Plant Sciences. 2012; 5(3):102-109. doi: 10.5829/idosi.ajps. 2012.5.3.6279.

12. Qu F, Chen Q, Ding Y, Liu Z, Zhao Y, Zhang X, Liu Z, Chen J. Isolation of a feather-degrading strain of bacterium from spider gut and the purification and identification of its three key enzymes. Mol Biol Rep. 2018; 45(6):1681-1689. doi: 10.1007/s11033-018-4311-8.

13. Arokiyaraj S, Varghese R, Ali Ahmed B, Duraipandiyan V, Al-Dhabi NA. Optimizing the fermentation conditions and enhanced production of keratinase from Bacillus cereus isolated from halophilic environment. Saudi J Biol Sci. 2019; 26(2):378-381. doi: 10.1016/j.sjbs.2018.10.011.

14. Gafar AA, Khayat ME, Ahmad SA, Yasid NA, Shukor MY. Response Surface Methodology for the Optimization of Keratinase Production in Culture Medium Containing Feathers by Bacillus sp. UPM-AAG1. Catalysts. 2020; 10(8):848. doi:10.3390/catal10080848.

15. Koutb M, Morsy FM, Bagy MMK, Hassan EA. Optimization of Extracellular Keratinase Production by Aspergillus terreus Isolated from Chicken's Litter. Journal of Advanced Laboratory Research in Biology. 2012; 3(3):210-216.

16. Nurliyana Mohamad, Lai-yee Phang, Suraini Abd-Aziz. Optimization of metallo-keratinase production by Pseudomonas sp. LM19 as a potential enzyme for feather waste conversion. Biocatal Biotransformation. 2017; 35(1):41-50. doi: 10.1080/10242422.2017.1280031.

17. Ezeme-Nwafor AC, George-Okafo UO, Nwachukwu UF. Production and optimization of keratinase enzyme by Bacillus safensis LRF3X isolated from feather dump sites. GSJ. 2020; $8(5): 257-270$.
18. Saber IA, El-Metwally MM, El-Hersh MS. Keratinase Production and Biodegradation of Some Keratinous Wastes by Alternaria tenuissima and Aspergillus nidulans. Res J Microbiol. 2010; 5:21-35. doi: 10.3923/jm.2010.21.35.

19. Ningthoujam DS, Devi LJ, Devi PJ, Kshetri P, Tamreihao K, et al. Optimization of Keratinase Production by Amycolatopsis sp. Strain MBRL 40 from a Limestone Habitat. J Bioprocess Biotech. 2016; 6(4):282. doi:10.4172/21559821.1000282.

20. Hui Ni, Qi-he Chen, Feng Chen, Ming-liang Fu, Ya-chen Dong, Hui-nong Cai. Improved keratinase production for feather degradation by $\mathrm{Ba}$ cillus licheniformis ZJUEL31410 in submerged cultivation. Afr J Biotechnol. 2011; 10(37):7236724. doi: 10.5897/AJB11.168.

21. Mousavi S, Salouti M, Shapoury R, Heidari Z. Optimization of Keratinase Production for Feather Degradation by Bacillus subtilis. Jundishapur J Microbiol. 2012; 6(8):7160. doi: 10.5812/ jjm.7160.

22. Tatineni R, Doddapaneni KK, Potumarthi RC, Mangamoori LN. Optimization of keratinase production and enzyme activity using response surface methodology with Streptomyces sp7. Appl Biochem Biotechnol. 2007; 141(2-3):187201. doi: 10.1007/BF02729061.

23. Bhari R, Kaur M, Singh RS. Optimization and validation of keratinase production by Bacillus aerius NSMk2 in a stirred tank reactor using response surface methodology. SN Appl Sci. 2021; 3:641. doi:10.1007/s42452-021-04629-x.

24. Dada M, Sherifah W. Production, Purification and Characterisation of Keratinases from Bacillus species Isolated From Poultry Feather Waste. Scientific Research Journal. 2020; 8(4):83-99. doi: 10.31364/SCIRJ/v8.i4.2020.

Received 7.10.2021 